\title{
The Differentiation of Triple Junction Telescopic Tube Space Maintainer From Space Maintainer Type I to Increase Intermolar With Premature Loss of Children
}

\author{
Laelia Dwi Anggraini ${ }^{1, *}$ Sunarno ${ }^{2}$ Rinaldi Budi Utomo ${ }^{3}$ Dibyo Pramono ${ }^{4}$
}

\author{
${ }^{1}$ Faculty of Dentistry, Universitas Gadjah Mada; School of Dentistry, Universitas Muhammadiyah Yogyakarta \\ ${ }^{2}$ Faculty of Engineering, Universitas Gadjah Mada \\ ${ }^{3}$ Faculty of Dentistry, Universitas Gadjah Mada \\ ${ }^{4}$ Department of Public Health, Universitas Gadjah Mada \\ *Corresponding author.Email: laelia.dwi@umy.ac.id; laelia_dentist@yahoo.com
}

\begin{abstract}
Background: Dental caries may lead to premature loss of the deciduous tooth. If it is left untreated it will lead to abnormal occlusion in children. The appliance used for preventive orthodontic is a space maintainer (SM). The existing appliance is rigid so far and does not follow the jaw growth. Thus, innovative design is required. Purpose: This study aims to compare the Triple Junction Telescopic Tube (TJTT SM) and Space Maintainer Type I (SM Type I) clinical result in terms of intermolar distance. Methods: This research is a clinical experiment non-randomized controlled trial research design. The subject was children ranging from 6-14 years old. The sample is taken with consecutive (non-probability sampling) and open-label, involving 30 subjects with SM type I treatment and 30 subjects with TJTT SM treatment, at Dental Hospital of Universitas Muhammadiyah Yogyakarta. Results: The results showed that the difference intermolar distances were $1.09 \mathrm{~mm}$ TJTT SM and $0.87 \mathrm{~mm}$ SM Type I. Conclusion: The conclusion is TJTT SM is capable of following the growth and development of the jaw in lateral (based on intermolar $1.09 \mathrm{~mm})$ and anterior $(1.12 \mathrm{~mm})$ also needs to be further developed.
\end{abstract}

Keywords: premature loss, triple junction telescopic tube, space maintainer

\section{INTRODUCTION}

Dental caries experienced by children might cause loss of dental crown which leads to teeth removal. The current common problem is that there have been deciduous molar teeth removal or early tooth loss which causes both sides of mesial and distal teeth to tend to shift into the cavity ${ }^{[1]}$. The shift towards the cavity would obstruct the growth of the permanent teeth. The dental as the movement or process of teeth shifting towards mouth cavity because it existed within the alveolar bone, the dental eruption is a varied process that occurs among children ${ }^{[2]}$. Dental eruption is commonly used to predict a child's age. Besides dental maturation, dental eruption is also influenced by the factor of caries and dental removal ${ }^{[3]}$. Children's teeth commonly erupt at the age of six until eight months eventually going into the final phase at the age of 2.5 until 3 years. At the age of 6 until 12 years, the primary teeth begin to be replaced by the permanent ones. Permanent teeth tend to more likely encounter problems during the eruption process rather than the primary teeth. The growth process problem either on primary or permanent teeth could influence the dental eruption duration ${ }^{[4]}$. Preventive orthodontic treatment is needed in mixed dentition age children. Losing a deciduous tooth will also inhibit jaw growth $^{[6]}$. The malocclusion treatment needs to be given since early childhood to gain maximum treatment results. This refers to the fact that before reaching maturity, craniofacial bone growth is more significant ${ }^{[5]}$. The facial bone growth proceeds rapidly during infancy, slowing down progressively during childhood, and the minimum growth rate occurs at prepuberty period. The growth rate increases again during puberty and decreases during the maturity period ${ }^{[6]}$. The knowledge of cranium and jaw, especially maxilla and mandibular, is important that it can be used as a guideline in deciding the proper treatment plan. The maxilla and mandibular length average standard enables dentists to decide whether the abnormality experienced by children requires immediate intensive treatment ${ }^{[6]}$. Cranium grows fast before birth and then keeps growing fast until the age of 1 year as brain skull formation. Since early childhood, cranium would grow steadily until the maturity period. In facial growth, the peak of growth takes place upon the birth period and slows down significantly during the pre-puberty period. Female children experience 2-year faster growth compared to male children. Peak growth would occur during puberty and then slows down until eventually stop at late adolescence. The peak growth of females takes place at the age of 11 until 13 years $^{[7]}$.

Since the beginning of the $20^{\text {th }}$ century, fixed or removable space maintainer has been used by pediatric dentist. This appliance is used as one of the efforts to prevent 
dental shifting the premature loss on the deciduous teeth. Space maintainer (SM) is an appliance that is capable of maintaining the space due to premature loss until the permanent teeth are ready to substitute ${ }^{8}$. The treatment of SM needs to be given so that the permanent teeth would not grow too early ${ }^{[9]}$. SM functions in the way it holds the space since the disappearance of curvature length causes structural imbalance and functional efficiency ${ }^{[1]}$. The diagnosis is based on the patient's medical record. This is due to the initial extraction when the tooth was removed ${ }^{[10]}$.

There has been a high rate of patients who require SM treatment. This appliance is quite expensive and malfunction therapy would cause a blocked space, thus ending with crowded teeth. This malfunction leads to dental malocclusion as well as masticatory disorder. A further consequence that might occur is the dento-maxillofacial growth disorder which makes facial development interference. These potential impacts could be the factor of space maintainer treatment absence $^{[11]}$. According to Mc Donald et al. (2015), the function of SM is to maintain the available space because the loss of arch length results in a loss of structural balance and functional efficiency.

Currently available space maintainer is the one with rigidstatic acrylic material. Due to the appliance's nature, some parts of the appliance's application need to be re-applied, when the incisive central dental is erupting since it requires more space than incisive lateral deciduous ${ }^{[9]}$. Other SM drawback is that it ignores the principles of normal jaw growth $^{[12]}$. The Current space maintainer has not performed an inline jaw movement either with lateral or anteroposterior direction. Due to the mentioned drawbacks, applied SM is impossible to be re-applied, thus patients would have to spend new SM application expenses ${ }^{9}$.

Space maintainer treatment on children aims to maintain the space to prevent constriction ${ }^{[13]}$. A simple SM modification can be used to replace the missing maxillary central incisors ${ }^{[14]}$. Effective SM appliance is the one that considers lateral direction jaw growth ${ }^{[12]}$ The development of the removable SM appliance by installing two tubes in the middle of the acrylic plate gap, by which it applies to all patients, this appliance is subsequently called as SM Type I. This developed appliance focuses only on the lateral direction growth $^{[11]}$.. Therefore, an effective SM build design method which adjusts inline jaw growth with the lateral direction is required ${ }^{[12]}$.

Based on the explanation regarding the effective SM appliance design, a modification of the SM appliance according to the lateral and anteroposterior jaw direction needs to be conducted. This design emphasizes the triple junction telescopic tube space maintainer (TJTT SM) which is installed within the acrylic plate. The function of this design is to create an anterior and lateral direction adjustment. Meanwhile, the function telescopic tube's installed in the plate is the marker of the jaw growth direction. The existence of the triple junction telescopic tube is related to the appliance balance. The telescopic tube's potential is dealing with the perfection of the ergonomic and balance so that it would create optimal cavity prevention for children. It is expected that TJTT SM adjusts the jaw growth with lateral direction.

This research aims to prove the TJTT SM clinic test result for the point of view of the intermolar distance. The benefit of this research is that effective and innovative SM design could be achieved, by which it takes lateral movement into account and explores more advantages of triple junction telescopic tube space maintainer (TJTT SM) implemented to children as patients at RSGM. Severe dental caries experienced by children causes dental crown obliteration, which eventually leads to teeth removal. The current common problem is that there have been deciduous molar teeth removal or early tooth loss which causes both sides of mesial or distal teeth to tend to shift into the space. The shift towards the space would halt the growth of the permanent tooth ${ }^{1}$. The teeth eruption, as the movement or process of teeth shifting towards mouth cavity since it existed within the alveolar bone, is a varied process that occurs among children ${ }^{[2]}$. Tooth eruption is commonly used to predict a child's age. Besides tooth maturation, tooth eruption is also influenced by the factor of caries and dental removal ${ }^{[15]}$. Children's teeth commonly erupt at the age of six until eight months which eventually go into the final phase at the age of 2.5 until 3 years. At the replaced by the permanent ones. Permanent teeth tend to more likely encounter problems during the eruption process rather than the primary teeth. The problem of growth process either on primary or permanent teeth could influence the timing of eruption of the tooth ${ }^{[16]}$.

The novelty of this research is the placement of the tube on the preventive orthodontic appliance in the maxilla.

\section{MATERIALS AND METHOD}

This research involved quasi clinical experimental tests on children as patients. The samples was taken based on the registered patients at RSGM in Yogyakarta. There was 60 research subjects, under informed consent from the parents, including patients who require space maintainer (SM) treatment. The subjects were randomly divided, in which TJTT SM was implemented to 30 patients, whereas SM Type I was implemented to the rest 30 patients. The sampling process was carried out consecutively (non-probability sampling). The sample was given anamnesis, subjective, and objective examination as well as dental x-ray service (OPG and periapical). The ethical clearance number 0001/KKEP/FKGUGM/EC/2019.

The next process, the samples been taken dental impression to get study and work models the samples been taken dental impression to get study and work models, was the appliance designing process at Laboratorium Teknik Gigi (Dentistry Technical Laboratory), Rumah Sakit Gigi dan Mulut (Dental Hospital), Universitas Muhammadiyah Yogyakarta, followed by the process of initial clinical test, final clinical test, and final analysis. All test done in the patients. After that, a clinical trial was carried out on the 
Triple Junction Telescopic Tube Space Maintainer to monitor lateral movement. TJTT SM compared to Type I SM.

The patients' parents would then fill out the informed consent. The research subjects were both male and female of a 6 - 14 year-old. The subjects were diagnosed, then calculated using the Moyers, Huckaba method, the mesio distal tooth method, and the arch determination method. The subjects fulfilled the criteria if the calculation result shows a $2-4 \mathrm{~mm}$ dental space gap.

The subjects were observed for 9 times of check-ups, with control period of 3 months to 8 months. In each control a measurement was taken (measuring instrument used in this case is a tapered sliding caliper, Vernier Caliper Tricle Brand, serial number $150 \mathrm{~mm} / 6 \times 0.05 / 1 / 128)$. The first was the intermolar width, the width between the mesio crow of the right and left mesia crowns of the permanent molar teeth. The intermolar width increase indicated the changes in the lateral direction of the jawbone. Next, it was observed that the gaps or space in the missing tooth was fixed (unchanged). The fixed distance indicated that the space maintainer's function as a means to maintain space. Furthermore, it is observed that the gaps or space in the cleavage of the acrylic space maintainer had changed (increasing the width). The increased gap was indicated by the lateral (intermolar) development of the jawbone.

It is shown in Figure 1 for the scheme of SM Type 1 and in Figure 2 for the scheme of TJTT SM.

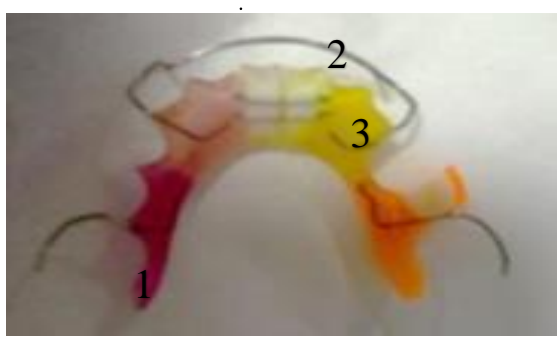

Figure 1. SM Type I (patient's photo)

(1.C-clasp; 2. Labial-arch; 3. Single tube)

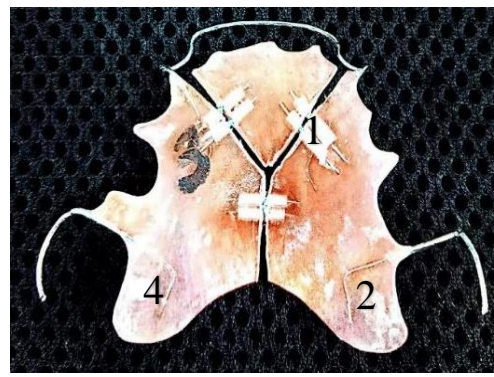

Figure 2. TJTT SM

1.Labial arch, 2. C claps, 3. TJTT Lateral Direction Design; 4. Plate

\section{RESULTS}

Based on Table 1 below, the research subjects were divided into two groups, namely the Type I SM group and the space maintainer group with the Triple Junction Telescopic Tube (TJTT SM) model. Each group consisted of 30 research subjects (respondents).

Table 1. The characteristics oral hygiene of the research subjects

\begin{tabular}{lrrrr}
\hline Variable & Group & & Statistics & $p$-value \\
\cline { 2 - 4 } & SM Type I & TJTT SM & & \\
\hline Oral Hygiene & & & \\
Good & $2893.30 \%)$ & $2893.30 \%)$ & $x^{2}=0.46$ & 1.00 \\
Moderate & $2(6.70 \%)$ & $2(6.70 \%)$ & & \\
\hline
\end{tabular}

Table 2. The characteristics of the research subjects

\begin{tabular}{lcccc}
\hline Variable & Group & & Statistics & $p$-value \\
\cline { 2 - 5 } & SM Type I & TJTT SM & & \\
\hline Nutritional Status & & & \\
Good & $2893.30 \%)$ & $2790.00 \%)$ & $x^{2}=0.46$ & 1.00 \\
Moderate & $2(6.70 \%)$ & $310.00 \%)$ & & \\
Socio-Economic Status Sosial & & & \\
Good & $2(6.7 \%)$ & $1(3.3 \%)$ & $x^{2}=0.59$ & 1.00 \\
Moderate & $28(93.3 \%)$ & $29(96.7 \%)$ & & \\
\hline Respondent=n & 30 & 30 &
\end{tabular}

Referring to Table 2, it can be seen that the results of the research subjects characteristics based on their nutritional status showed that the two groups, both Type I and TJTT SM, were mostly well-nourished ( $\mathrm{n}=28$ subjects with Type I SM), with the $x^{2}$ value of 0.463 and $p=1$. Based on the socioeconomic status (with the take home pay), most of the subjects of both Type I and TJTT SM had moderate socioeconomic status ( $\mathrm{n}=28$ subjects of Type I SM; $\mathrm{n}=29$ subjects of TJTT SM), with the $\mathrm{x} 2$ value of 0.59 and $\mathrm{p}=1$. Meanwhile, in the Table I, from the oral perspective hygiene, all research subjects, both Type I and TJTT SM, had oral hygiene in a good and moderate category $(n=30$ subjects, Type I and TJTT SM).

Based on Table 3, the research subjects were divided into two groups, namely the Type I SM group and the Triple Junction Telescopic Tube Space Maintainer (TJTT SM) group. Each group consisted of 30 research subjects (respondents). The comparison of the intercanine gaps between the Type I SM group with the TJTT SM model was taken. Type I SM had the mean of intermolar gaps increase of $0.87 \mathrm{~mm}$ and the standard deviation of $1.12 \mathrm{~mm}$, while TJTT $\mathrm{SM}$ had the mean of intermolar gaps increase of $1.09 \mathrm{~mm}$ with a standard deviation of $1.32 \mathrm{~mm}$. The comparison of the intermolar gaps increase between the Type I SM group and the TJTT SM group had a t value of -0.03 and p-value of 0.98 . In this study, the inter molar standard deviation (Type I 0.12; 
TJTT 0.32). Only 30 sample used in this study, because trouble finding this case.

Table 3. The comparison of the intermolar gaps increase $(\Delta)$ between SM Type I Group and TJTT SM Group

\begin{tabular}{lllll}
\hline Statistics & Group & t & p-value \\
\cline { 2 - 5 } & $\begin{array}{l}\text { SM Type I } \\
(\mathbf{m m})\end{array}$ & $\begin{array}{l}\text { TJTT } \boldsymbol{S M} \\
(\mathbf{m m})\end{array}$ & & \\
\hline Mean & $0.87 \mathrm{~mm}$ & $1.09 \mathrm{~mm}$ & -0.03 & 0.98 \\
$\begin{array}{l}\text { Standard } \\
\text { Deviation }\end{array}$ & 0.12 & 0.32 & & \\
$\begin{array}{l}\text { Number of } \\
\text { Subjects }\end{array}$ & 30 resp. & 30 resp. & & \\
\end{tabular}

Based on Table 4, the research subjects having the comparative data on anteroposterior gaps were the space maintainer group of the Triple Junction Telescopic Tube (TJTT SM) model. The mean of anteroposterior gaps increase of the TJTT SM group was 1.1233 with a standard deviation of 0.54752 . On the other hand, for Type I, the increase could not be measured so that the TJTT SM and SM Type I could not be compared statistically.

Table 4. The anteroposterior gaps increase $(\Delta)$ of TJTT SM group (mm)

\begin{tabular}{ll}
\hline Statistics & TJTT SM \\
\hline Mean & $1.12 \mathrm{~mm}$ \\
Standard Deviation $(\Delta)$ & $0.55 \mathrm{~mm}$ \\
Number of Subjects & 30 respondents \\
\hline
\end{tabular}

The comparison results of the TJTT SM and SM Type I were presented in Table 5 shown that there is no significant difference between TJTT SM and SM Type I for the gaps intermolar.

Table 5. The Comparison Results of TJTT SM ( $n=30$ subjects) dan SM Type I ( $\mathrm{n}=30$ subjects)

\begin{tabular}{|c|c|c|c|c|c|c|}
\hline \multirow{2}{*}{$\begin{array}{l}\text { Varia } \\
\text { ble }\end{array}$} & \multicolumn{3}{|c|}{ TJTT SM } & \multicolumn{3}{|c|}{ SM Type I } \\
\hline & $\begin{array}{l}\text { Initial } \\
\text { Mean } \\
\text { Value } \\
(\mathbf{m m})\end{array}$ & $\begin{array}{l}\text { Final } \\
\text { Mean } \\
\text { Value } \\
(\mathbf{m m})\end{array}$ & $(\Delta)$ & $\begin{array}{l}\text { Initial } \\
\text { Mean } \\
\text { Value } \\
(\mathbf{m m})\end{array}$ & $\begin{array}{l}\text { Final } \\
\text { Mean } \\
\text { Value } \\
(\mathbf{m m})\end{array}$ & $(\Delta)$ \\
\hline $\begin{array}{l}\text { Inter } \\
\text { molar }\end{array}$ & 40.34 & 41.44 & 1.09 & 42.82 & 44.64 & 0.87 \\
\hline
\end{tabular}

The patients had completely treated, showing that there was a maxillary growth that can be monitored from the SM TJTT movement. All patients (60 subjects) had initial and final OPG X-rays which were available to monitor the lateral jaw growth.

\section{DISCUSSION}

This research which was a clinical test, was carried out in a clinical experimental manner covering anamnesis, oral examination, dental photography, work models, work models measurement, diagnosis and treatment plan drawing. Furthermore, the initial clinical examination, final clinical examination, and results analysis were carried out. The working concept of TJTT SM is that the change in the angle at the beginning and the end of the treatment occurs, marked by the decreasing angle, indicating that there are anterior growth and development. In addition, the length of the arm in the cleavage is shown by the arm length, which indicates the lateral growth and development. It is according to the theory mentioning that the force acting on the jaw is the lateral force following the jaw's growth to the right and left ${ }^{[6]}$.

TJTT SM with the ability to stretch on the lateral and anterior sides is expected to be able to last longer in children's oral cavity making the children do not need to change the appliances every month. This TJTT SM research did not examine the period span of the TJTT SM appliances used. Previous studies have suggested that the patients can use SM Type I for a period of 2 months to 5 months. After that, it should be replaced as it is getting tighter ${ }^{6}$. The orthodontic interventions are often initiated with dentition development to promote beneficial developmental changes. The safest way to prevent malocclusion from the impact of future tooth loss is to put an effective and durable space maintainer ${ }^{[19]}$.

During the final appliance insertion and control, maxillary stone gips model was given to the subjects to compare the intercanine and intermolar widths. The preventive orthodontic treatment, such as the use of space maintainers, serves as the initial treatment before malocclusion occurs. It is recommended to pay attention to the aspects of childhood development. The care for children and adolescent patients influenced by the growth and development factors cannot be done in the same way as adult orthodontic patients ${ }^{[19]}$.

Referring to Table 2, the distribution of age is evenly found for the patients aged 7-14 years. The patient's nutritional status was relatively good in both TJTT SM group and Type I SM groups. Based on the socio-economic status, the majority of the subjects in both Type I and TJTT SM groups were in middle socioeconomic status. In terms of oral hygiene characteristics, all research subjects in both Type I and TJTT SM groups had good oral hygiene (Table I). The space maintainer, assists the child in both functional and aesthetics aspects, by reducing future expenses in orthodontics. The space maintainers prevent tooth movement and inclination, loss of space for permanent teeth, crowding and impaction ${ }^{[23]}$.

This clinical study selected the subjects having a space maintainer treatment indication, namely subjects who had lost the maxillary teeth; one or more teeth. The diagnosis is based on the missing teeth and the space analysis of Moyers, Huckaba, and Arch Determination. This refers to the theory highlighting that the effects of tooth eruption and the number 
of abnormalities that may occur in the oral cavity will help dentists determine the appropriate diagnosis and therapy ${ }^{[20]}$.

Referring to Table 3 and Table 4, TJTT SM following lateral and anterior jaw growth is expected to last in children's jaw as long as possible. Basically, the space maintainer is a prosthesis in children's. Previous studies have revealed that a dental prosthesis (artificial) is a functional aid appliance serving as the substitute for teeth that have been extracted or lost. This preventive tool aims to restore chewing function, aesthetic function and restore children's self-confidence ${ }^{[6]}$

The clinical research referring to Table 5 showed that changes in jaw growth in the subjects were the results of the 9-times-control observations. The obedience in using the appliances also encouraged treatment success. This result is in accordance with previous studies that patient obedience in using the appliances and the supervision of elderly subjects shows the maximum results ${ }^{[19]}$. Regarding the role of dentists in caring and educating pediatric patients, it highlights to the concept that bad self-concept in children can be overcome by bringing in counselors from both the health and psychological perspectives so that the children and the environment pay more attention to the children's psychological development ${ }^{[17]}$. The development process of children differs according to psychological conditions. For example, a kindergarten student in the early stage and an elementary school student in the child's final stage have differences in physical motor, knowledge, socio-emotional, talks, and religious development ${ }^{[21]}$.

The clinical study referring to Table 5 showed that there was no significant difference from the intermolar measurements based on the final data analysis. The study also showed that the development of the maxilla ranged from 0.87 - $1.09 \mathrm{~mm}$. There was no difference in the intermolar distance in subjects TJTT SM and with Type I SM. It is understood that overgrowth is worrying as the jaw growth develops from millimeters to millimeters. This result is consistent with previous studies noting that the gold standard of lateral growth of children aged 5-11 years ranges from 1-2 $\mathrm{mm}^{[22]}$. There is a significant increase in the frequency of orthodontic treatment in patients who prematurely lose one or more primary teeth ${ }^{[24]}$.

The table above shows that conditions of oral hygiene, diet, socioeconomic support preventive care treatment. Early diagnosis followed by an accurate treatment plan for each case is essential. Pediatric dentists are in a strategic position to provide early diagnosis through the child's dental history and by providing orthodontic preventive care ${ }^{[25]}$.

The conclusion is TJTT SM is capable of following the growth and development of the jaw in lateral (based on intermolar $1.09 \mathrm{~mm})$ and anterior $(1.12 \mathrm{~mm})$ also needs to be further developed.

\section{AUTHORS' CONTRIBUTIONS}

Researchers developed a space maintainer shape that was compatible with the lateral growth and development of the child's maxillary jaw.

\section{ACKNOWLEDGMENTS}

The authors thank the Ministry of Research, Technology, and Higher Education Indonesia for the BUDI-DN scholarship with the grant number FR8102018158863 and Dental Hospital Universitas Muhammadiyah Yogyakarta, Yogyakarta, for the willingness to be the subject in this research.

\section{REFERENCES}

[1]. Donald M, Avery. Dentistry for the Child and Adolescent. 9th ed. Mosby Co., St. Louis, Missouri; 2015. 221-223 p.

[2]. Lantu VAR, Kawengian SES, Wowor VNS. Hubungan Status Gizi dengan Erupsi Gigi Permanen Siswa SD Negeri 70 Manado. eG [Internet].2015Feb1[cited2020Aug24];3(1).Available ,from:https://ejournal.unsrat.ac.id/index.php/egigi/arti cle/view/6849

[3]. Sitinjak ACH, Gunawan PN, Anindita PS. Hubungan Status Gizi dengan Erupsi Gigi Molar Pertama Permanen Rahang Bawah pada Anak Usia 6-7 Tahun di SD Negeri 12 Manado. eG [Internet]. 2019 Jan18[cited2020Sep6];7(1).Available,from:https://ejo urnal.unsrat.ac.id/index.php/egigi/article/view/23308

[4]. Amrullah SSA, Handayani H. Faktor-faktor yang mempengaruhi keterlambatan erupsi gigi permanen pada anak. 2018;5.

[5]. Sharma A, Tabassum A. Evaluation of patient satisfaction for retention, masticatory efficacy, aesthetics and comfort for Removable Partial denture: A Retrospective study. International Journal of Applied Dental Sciences. 2018;

[6]. Nanda. Biomechanic in Clinical Orthodonsia. Saunders Co., St. Louis, Missouri; 2014. 21-23 p.

[7]. Neinstein LS. Puberty, Normal Growth, and Development. University of Southern California, USA; 2014.

[8]. Goel S, Singh A, Chaudhary G, Kalsi DS, Sood A, Marria G. The Relationship of Malocclusion with Periodontal Status, Dental Caries, and Sociodemographic Factors in School Children of Ludhiana. Indian Journal of Dental Sciences. 2018;10(2):5

[9]. Pinkham. Pediatric Dentistry. 4th ed. WB Saunders and Co, Philadelphia; 2013. 242-256 p.

[10]. Snawder KD. Handbook of Clinical Pedodontics. St Louis, Missouri, USA; 2017. 242-275 p.

[11]. Anggraini L. Evaluasi Space Maintainer dan Space Regainer pada Pasien Anak di RSGM UMY, Yogyakarta. Proceeding Dream III Yogyakarta. 2016;34. 
[12]. Finn. Pediatric Dentistry. Mosby \& Co, USA; 2015. 161-166 p.

[13]. Pamungkas RB. Space Maintainer Treatment in Premature Loss Deciduous Tooth. 2020;5(1):12.

[14]. Testori T, Weinstein T, Scutellà F, Wang H, Zucchelli G. Periodontology 2000. Vol. 77. 2018.

[15]. Variani R. Perbandingan Waktu Erupsi Gigi Susu Incisivus Pertama Pada Bayi Usia Yang Diberi Susu Asi Dan Yang Diberi Susu Fomula. jik. 2018 Jun $4 ; 16(1): 21-31$.

[16]. Amrullah SSA, Handayani H. Faktor-faktor yang mempengaruhi keterlambatan erupsi gigi permanen pada anak. $2017: 5$.

[17]. Rochmah SN. Hubungan Konsep Diri Guru Terhadap Regulasi Diri Anak Usia Dini. Tunas Siliwangi. 2017 Oct;3(2):160 - 174.

[18]. Patil PG. Implants or Pontics. J Am Dent Assoc. 2013

[19]. Zuhri A, Ikawati NT, Pawinru AS. Penerapan prinsip perawatan ortodontik dewasa terhadap pasien anak dan remaja yang mengganggu proses tumbuhkembang. 2017;6.

[20]. Marjianto A, Sylvia M, Wahluyo S. Permanent tooth eruption based on chronological age and gender in 612-year old children on Madura. Dent J (Maj Ked Gigi). 2019 Jun 30;52(2):100.

[21]. Khaulani F, S N, Irdamurni I. Fase dan Tugas Perkembangan Anak Sekolah Dasar. JIPD. 2020 Jan 29;7(1):51.

[22]. Koesoemahardja HD. Tumbuh Kembang Dentofasial Manusia. Jakarta: Universitas Trisakti; 2013.

[23]. Tatiane Maciel de Carvalho and Alexandre Franco Miranda, Preventive Orthodontics: Space Maintainers in the Early Loss of Deciduous Tooth - Clinical Case Report. EC Dental Science 10.5 (2017): 143-148. Received: May 03, 2017; Published: May 25, 2017.

[24]. I. B. Davenport, The significance of the natural form and arrangement of the dental arches of man, with a consideration of thechanges which occur as a result of their artificial derangement by filling or by the extraction of teeth, Dental Cosmos, vol. 29, 2014.

[25]. Simona Tecco, Mariano Lacarbonara, Maria Teresa Dinoi, Gianni Gallusi, Enrico Marchetti, Stefano Mummolo, Vincenzo Campanella \& Giuseppe Marzo, The retrieval of unerupted teeth in pedodontics: two case reports, Journal of Medical Case Reports volume 8, Article number: 334 (2014) 